\title{
Urgensi Audit Delay: Antara Total Asset, Profitabiltas dan Fee Audit Pada Perusahaan Industri Manufaktur yang Terdaftar di Bursa Efek Indonesia
}

\author{
Bahtiar Effendi \\ Universitas Matana, Tangerang, Indonesia \\ bahtiar.effendi90@gmail.com
}

\begin{abstract}
This study aims to determine the effect of total assets, profitability and audit fees on audit delay of manufacturing industry companies listed on the Indonesian stock exchange. This study uses a quantitative approach. The data collection technique used in this study is the documentation method, which is by collecting and recording financial statements. The data source used is secondary data in the form of financial statements of manufacturing industry companies listed on the Stock Exchange for the period 2016-2018 which can be obtained through the site www.idx.co.id. The sampling technique used was purposive sampling with 39 units of data analysis. The data analysis method used is multiple linear regression analysis using the SPSS 24.0 program. The results showed that (1) total assets had a significant positive effect on audit delay of manufacturing industry companies listed on the Indonesia Stock Exchange. (2) Profitability has a negative or no significant effect on audit delay of manufacturing industry companies listed on the Indonesia Stock Exchange, (3) Audit fee has a significant positive effect on audit delay of manufacturing industry companies listed on the Indonesia Stock Exchange.
\end{abstract}

Keywords: Audit Delay, Total Assets, Profitability, Audit Fee.

Abstrak- Penelitian ini bertujuan untuk mengetahui pengaruh total aset, profitabilitas, dan biaya audit terhadap audit delay perusahaan industri manufaktur yang terdaftar di bursa efek Indonesia. Penelitian ini menggunakan pendekatan kuantitatif. Teknik pengumpulan data yang digunakan dalam penelitian ini adalah metode dokumentasi, yaitu dengan mengumpulkan dan mencatat laporan keuangan. Sumber data yang digunakan adalah data sekunder berupa laporan keuangan perusahaan industri manufaktur yang terdaftar di Bursa Efek untuk periode 2016-2018 yang dapat diperoleh melalui situs www.idx.co.id. Teknik pengambilan sampel yang digunakan adalah purposive sampling dengan 39 unit analisis data. Metode analisis data yang digunakan adalah analisis regresi linier berganda dengan menggunakan program SPSS 24.0. Hasil penelitian menunjukkan bahwa (1) total aset berpengaruh positif signifikan terhadap audit delay perusahaan industri manufaktur yang terdaftar di Bursa Efek Indonesia. (2) Profitabilitas berpengaruh negatif atau tidak signifikan terhadap audit delay perusahaan industri manufaktur yang terdaftar di Bursa Efek Indonesia, (3) Fee audit berpengaruh positif signifikan terhadap audit delay perusahaan industri manufaktur yang terdaftar di Bursa Efek Indonesia.

Kata Kunci: Audit Delay, Total Assets, Profitability, Audit Fee.

\section{PENDAHULUAN}

Laporan keuangan perusahaan merupakan instrumen yang wajib dimiliki oleh perusahaan besar yang bergerak dalam bidang bisnis, salah satunya adalah bidang manufaktur. Manufaktur adalah suatu cabang industri yang mengaplikasikan peralatan dan suatu medium proses untuk transformasi bahan mentah menjadi barang jadi untuk dijual. Laporan keuangan yang dipublikasikan ke publik, setidaknya meliputi laporan posisi keuangan (neraca), laporan laba rugi komprehensif, laporan arus kas, laporan perubahan ekuitas, dan catatan atas laporan keuangan.

Tujuan laporan keuangan adalah hasil dari proses akuntansi yang menyajikan posisi keuangan dan kinerja keuangan dalam suatu entitas, dan dapat digunakan sebagai alat untuk berkomunikasi dengan pihak-pihak yang berkepentingan dengan data atau aktivitas perusahaan (Ikatan Akuntansi Indonesia, 2018). Laporan keuangan sebaiknya dibuat dan dipublikasikan dengan segera agar tidak 
mempengaruhi kapasitasnya dalam mempengaruhi pengambilan keputusan para penggunanya. Dengan demikian, perusahaan diharapkan untuk tidak menunda dalam menyajikan laporan keuangan karena dapat mengurangi manfaat dari informasi yang disajikan.

Keputusan Ketua Badan Pengawas Pasar Modal (BAPEPAM) dan Lembaga Keuangan (LK) Nomor: KEP-346/BL/2011 mewajibkan setiap emiten dan perusahaan publik yang terdaftar di Bursa Efek untuk menyampaikan laporan keuangan tahunan disertai dengan laporan akuntan dalam rangka audit atas laporan keuangan yang memuat opini audit dari akuntan kepada BAPEPAM dan LK paling lama 3 bulan (90 hari) setelah tanggal laporan keuangan tahunan. Pada 1 Agustus 2012 BAPEPAM dan LK mengeluarkan peraturan XK 6 pada lampiran Nomor: Kep-431/BL/2012 yang menyatakan bahwa emiten atau perusahaan publik yang pernyataan pendaftarannya telah menjadi efektif wajib menyampaikan laporan keuangan dan laporan akuntan kepada BAPEPAM dan LK paling lama 4 (empat) bulan setelah tahun buku berakhir. Jika regulasi dilanggar, maka akan dikenakan sanksi. Sanksi dapat berupa peringatan, sanksi administratif, dan sanksi denda.

Ketepatan waktu penyajian laporan keuangan merupakan syarat utama bagi peningkatan harga pasar saham perusahaan-perusahaan go public. Ketepatan waktu penyampaian laporan mengacu pada informasi yang lebih berguna untuk pengambilan keputusan. Dengan adanya audit delay dapat mempengaruhi ketepatan waktu informasi laporan keuangan yang dikeluarkan. Maka dari itu, audit delay merupakan hal yang penting dalam penelitian yang berhubungan dengan ketepatan waktu penyampaian laporan keuangan.

Salah satu penyebab perusahaan mengalami keterlambatan penyampaian laporan keuangan dikarenakan auditor lamban dalam menyelesaikan pekerjaan auditnya. Dalam pengauditan dikenal istilah audit delay. Menurut Wiwik Utami (2006) audit delay adalah lamanya waktu penyelesaian audit yang diukur dari tanggal penutupan tahun buku dan hingga tanggal diselesaikannya laporan audit independen. Semakin lama auditor menyelesaikan pekerjaan auditnya, maka audit delay akan semakin lama juga. Jika terjadi penundaan yang cukup lama mengenai penyampaian laporan keuangan, maka relevansi laporan keuangan tersebut dapat diragukan. Selain itu, penyampaian keuangan yang terlambat dapat berdampak negatif terhadap perusahaan dan dalam pengambilan keputusan manajemen.

Berdasarkan penelilti terdahulu yaitu Aryaningsih (2014) Setiap perusahaan harus mengetahui faktor-faktor penyebab audit delay sehingga bisa meminimalisis terjadinya audit delay yang lebih panjang. Hal tersebut akan berkaitan dengan citra perusahaan apabila audit delay yang dilakukan auditor semakin lama. Citra perusahaan yang tercemar dapat berpengaruh terhadap naik turunnya efek khususnya saham yang dijual di BEI, dengan menggunakan metode purposive sampling dan sample sebanyak 144 perusahaan dan teknik analisis data regresi linier berganda, hasil pengujian menunjukan bahwa variable total asset tidak berpengaruh pada audit delay. Menurut penelitian oleh Aryaningsih (2014) diperoleh hasil total asset tidak berpengaruh terhadap audit delay, Sama halnya dengan penelitian Deasy (2018), menurutnya setelah melakukan penelitian tentang Total asset kepada audit delay berpengaruh signifikan negatif dengan audit delay secara parsial, dan dapat disimpulkan bahwa semakin banyak total aktiva maka semakin kecil audit delay yang akan terjadi, namun berdasarkan Apriani (2017) dan menurut Fatma (2015) juga mengatakan bahwa total asset berpengaruh positif terhadap audit delay karena menurutnya semakin banyak asset yang dimilikinya, sehingga auditor perlu mengambil sampel audit yang lebih banyak. karena sampel audit yang diambil semakin banyak, maka auditor tentunya membutuhkan waktu yang lebih panjang ketika melakukan penugasan audit di perusahaan besar daripada di perusahaan kecil.

Selanjutnya menurut Fatma, dan Suzan (2015) diperoleh hasil yang menyatakan profitabilitas berpengaruh pada audit delay secara signifikan, namun beda hal menurut menurut Nurahman (2017) Apriani (2017) dan profitabilitas menunjukan tidak berpengaruh terhadap audit delay pada perusahaan properti di penelitiannya, menjadi perhatian utama stakeholder sehingga auditor akan lebih berhati-hati dalam melakukan audit terutama terhadap pos-pos yang menjadi faktor penyebab menunrunnya tingkat profitabilitas perusahaan.

\subsection{Rumusan Masalah}

Berdasarkan latar belakang masalah di atas, dapat disusun permasalahan sebagai berikut:

a. Apakah total asset berpengaruh positif terhadap audit delay?; 
b. Apakah profitabilitas berpengaruh positif terhadap audit delay?;

c. Apakah fee audit berpengaruh positif terhadap audit delay?.

\subsection{Tujuan Penelitian}

Berdasarkan permasalahan yang telah diuraikan di atas, maka tujuan penelitian ini adalah:

a. Untuk menganalisis pengaruh positif total asset terhadap audit delay;

b. Untuk menganalisis pengaruh positif profitabilitas terhadap audit delay;

c. Untuk menganalisis pengaruh positif fee audit terhadap audit delay.

\section{KAJIAN PUSTAKA}

\subsection{Teori Keagenan (Agency Theory)}

Pemisahan antara pengelola dan pemilik perusahaan sangat rentan terhadap masalah yang disebut sebagai masalah keagenan (agency problem). Sebuah perusahaan adalah pusat kontrak antara individu yang berpartisipasi dalam operasi perusahaan. Dalam teori ini, hubungan agensi muncul ketika satu orang atau lebih (principal) mempekerjakan orang lain (agent) untuk memberikan suatu jasa dan kemudian mendelegasikan wewenang pengambilan keputusan kepada agent tersebut (Jensen dan Meckling, 1976). Menurut Scott (2003:305) konsep teori keagenan merupakan hubungan atau kontrak antara principal dan agent, dimana principal merupakan pihak yang memperkerjakan agent agar melakukan tugas untuk kepentingan principal, sedangkan agent merupakan pihak yang menjalankan kepentingan principal.

Dalam penelitian ini yang akan kita bahas ialah audit delay yang dikerjakan oleh auditor independen secara professional terhadap perusahaan manufaktur (Consumer Goods Industry) yang terdaftar di BEI. Menurut Jensen dan Meckling (1976) terdapat dua permasalahan akibat asimetri informasi yakni Moral Hazard dan Adverse Selection. Namun kontrak antara agen dan prinsipal sulit terlaksana akibat adanya asimetri informasi, untuk meredam konflik ini maka diperlukan pihak ketiga sebagai penengah yaitu auditor independen (Anthony dan Govindarajan, 2005). Berbagai riset yang berhubungan dengan teori ini memfokuskan perhatian pada bagaimana agar sistem perjanjian kontrak kompensasi bisa mencapai keseimbangan. Alokasi kinerja perusahaan antara prinsipal dan agen didasarkan pada kontak tersebut, baik tertulis maupun tidak. Sistem kompensasi dalam kondisi yang ideal (first best) langsung dihubungkan dengan perilaku (Ikhsan dan Ishak, 2005:56).

Dari perspektif teori agensi, adanya gap antara atasan dan bawahan bisa menimbulkan kesenjangan informasi. Kesenjangan informasi tersebut bisa dikurangi dengan cara dilibatkannya manajer dalam pengambilan keputusan. Dapat dihipotesiskan bahwa semakin besar derajat informasi asimetri, semakin tinggi derajat penggunaan variabel partisipasi anggaran, yang berarti semakin tinggi tingkat kesenjangan informasi, semakin tinggi kemungkinan partisipasi anggaran tersebut ditetapkan.

\subsection{Audit Delay}

Ketepatwaktuan penerbitan laporan keuangan audit merupakan hal yang sangat penting, khususnya untuk perusahaan-perusahaan publik yang menggunakan pasar modal sebagai salah satu sumber pendanaan. Namun auditor memerlukan waktu yang cukup untuk dapat mengumpulkan bukti-bukti kompeten yang dapat mendukung opininya (Destiana, 2010).

$\begin{array}{rcc}\text { Ketepatan } & \text { waktu } & \begin{array}{c}\text { perusahaan } \\ \text { keuangan }\end{array} \\ \text { mempublikasikan } & \text { laporan }\end{array}$ masyarakat umum dan kepada BAPEPAM juga tergantung dari ketepatan waktu auditor dalam menyelesaikan pekerjaan auditnya. Keterlambatan informasi akan menimbulkan reaksi negatif dari pelaku pasar modal, karena laporan keuangan auditan yang di dalamnya memuat informasi penting, seperti laba yang dihasilkan perusahaan bersangkutan dijadikan sebagai salah satu dasar pengambilan keputusan untuk membeli atau menjual kepemilikan yang dimiliki oleh investor (Mantik dan Sujana, 2011).

Beberapa definisi mengenai Audit Delay yaitu:

Menurut Wiwik Utami (2006:4), Audit delay adalah lamanya penyelesaian audit yang diukur dari tanggal penutupan tahun buku, hingga tanggal diselesaikannya laporan audit independen. Menurut Rachmawati (2008), Audit delay adalah rentang waktu penyelesaian pelaksanaan audit laporan keuangan tahunan, diukur berdasarkan lamanya hari yang dibutuhkan untuk memperoleh laporan auditor 
independen atas audit laporan keuangan tahunan perusahaan, sejak tanggal tahun tutup buku perusahaan yaitu per 31 Desember sampai tanggal yang tertera pada laporan auditor independen.

Sedangkan menurut Subekti dan Widiyanti dalam Esynasali (2004), Audit Delay adalah perbedaan waktu antara tanggal laporan keuangan dengan tanggal opini audit dalam laporan keuangan mengindikasikan tentang lamanya waktu penyelesaian audit yang dilakukan oleh auditor. Beberapa faktor yang kemungkinan menjadi penyebab Audit Delay semakin lama, yaitu: Ukuran Perusahaan, Umur Perusahaan, Profitabilitas Perusahaan, Solvabilitas Perusahaan, Kualitas Auditor, dan Opini Auditor.

Audit delay ini akan menimbulkan dampak terhadap ketepatan publikasi informasi, dan informasi yang dipublikasikan dapat mempengaruhi penjualan kenaikan atau penurunan harga saham. Penundaan publikasi laporan keuangan akan memengaruhi tingkat ketidakpastian pengambilan keputusan. Hal ini dapat terjadi karena laporan keuangan yang dipublikasi secara tepat waktu adalah suatu kriteria utama yang dapat mencerminkan kenadalan data dalam pembuatan keputusan oleh investor yang ingin berinvestasi di bursa saham (Ismail et al, 2012). Semakin panjang audit delay maka semakin lama auditor dalam menyelesaikan pekerjaan auditnya (Subekti dan Widiyanti, 2004).

Audit delay diukur berdasarkan lamanya periode waktu penyelesaian audit dari akhir tahun fiskal perusahaan sampai tanggal laporan audit, yaitu per 31 Desember sampai tanggal yang tertera pada laporan auditor independen. Variabel ini diukur secara kuantitatif dalam jumlah hari.

\section{Audit delay $=$ Tanggal laporan audit - tanggal penutupan tahun buku}

\subsection{Total Asset}

Menurut Febrianty (2011) total asset atau ukuran perusahaan adalah suatu skala di mana dapat diklasifikasikan besar kecilnya perusahaan dengan berbagai cara antara lain dinyatakan dalam total aktiva, nilai pasar saham, dan lain-lain. Perusahaan yang memiliki asset yang lebih besar akan melaporkan lebih cepat dibandingkan dengan perusahaan yang memiliki asset yang lebih kecil. Hal ini disebabkan oleh perusahaan yang memiliki sumber daya (asset) yang besar memiliki lebih banyak sumber informasi, lebih banyak staf akuntansi dan sistem informasi yang lebih canggih, memiliki sistem pengendalian intern yang kuat, adanya pengawasan dari investor, regulator dan sorotan masyarakat, maka hal ini memungkinkan perusahaan untuk melaporkan laporan keuangan auditannya lebih cepat ke publik.

Jadi dapat disimpulkan bahwa, total asset merupakan cara dalam mengukur ukuran perusahaan. Apabila total asset suatu perusahaan adalah besar maka semakin singkat Audit Delay-nya. Hal tersebut disebabkan oleh ketatnya manajerial sistem pengendalian internal yang dimiliki oleh perusahaan sehingga selalu mengawasi aktivitas perusahaan yang dijalankan sebagaimana mestinya.

Perhitungan total asset diukur dengan berdasarkan jumlah seluruh asset perusahaan atau total aktiva perusahaan, baik asset lancar maupun asset tidak lancar. Variabel ini diukur dengan:

Total asset $=\log n$ (total asset)

\subsection{Profitabilitas}

Menurut Sunyoto (2013:113), profitabilitas adalah kemampuan perusahaan untuk memperoleh keuntungan dari usahanya. Disini permasalahannya adalah keefektifan manajemen dalam menggunakan baik total aktiva maupun aktiva bersih. Keefektifan dinilai dengan mengaitkan laba bersih terhadap aktiva yang digunakan untuk menghasilkan laba.

Dari definisi di atas dapat disimpulkan bahwa profitabilitas merupakan kemampuan perusahaan untuk menghasilkan keuntungan dalam hubungan dengan penjualan, total aktiva, maupun modal sendiri pada suatu periode waktu tertentu. Profitabilitas merupakan indikator untuk mengukur tingkat keberhasilan atau kegagalan perusahaan atau divisi tertentu sepanjang suatu periode waktu. Tingkat profitabilitas perusahaan dapat diukur melalui rasio profitabilitas. Semakin tinggi rasio profitabilitas maka laba yang dihasilkan akan semakin besar.

Adapun pengukuran variabel profitabilitas adalah sebagai berikut:

\section{Profitabilitas $=$ Laba bersih $/$ Total Asset}

\subsection{Fee Audit}

Fee audit merupakan imbalan yang diterima oleh auditor atas jasa audit yang telah dilaksanakan, besarnya fee yang diberikan bergantung pada risiko penugasan, kompleksitas jasa yang diberikan, dan tingkat keahlian yang diperlukan (Mulyadi 2002), 
selain itu juga dipengaruhi oleh faktor ukuran perusahaan klien serta nama KAP yang melakukan proses audit dan telah melalui kesepakatan kedua belah pihak. Adanya kesepakatan tersebut diharapkan agar auditor dapat menyelesaikan laporan auditnya secara tepat waktu tanpa mengurangi kualitas dari laporan itu sendiri. Adapun pengukuran variabel fee audit ini adalah sebagai berikut:

Fee Audit $=$ Jumlah imbalan yang diterima oleh auditor

\subsection{Pengembangan Hipotesis}

\subsubsection{Pengaruh Total Asset Terhadap Audit Delay}

Perusahaan yang memiliki asset yang lebih besar akan melaporkan lebih cepat dibandingkan dengan perusahaan yang memiliki asset yang lebih kecil. Hal ini disebabkan oleh perusahaan yang memiliki sumber daya (asset) yang besar memiliki lebih banyak sumber informasi, lebih banyak staf akuntansi dan sistem informasi yang lebih canggih, memiliki sistem pengendalian intern yang kuat, adanya pengawasan dari investor, regulator dan sorotan masyarakat, maka hal ini memungkinkan perusahaan untuk melaporkan laporan keuangan auditannya lebih cepat ke publik.

$\mathbf{H}_{1}$ : Total asset berpengaruh positif terhadap audit delay.

\subsubsection{Pengaruh Profitabilitas Terhadap Audit Delay}

Perusahaan publik yang mengumumkan tingkat profitabilitas rendah cenderung mengalami penerbitan laporan keuangan auditan dari auditor yang lebih panjang daripada perusahaan non publik (Ashton et al., 1987). Apabila perusahaan mengalami kerugian, pihak manajemen akan menunda untuk menerbitkan laporan tahunan perusahaan untuk menghindari adanya kabar buruk. Perusahaan yang mengalami kerugian dapat meminta auditor untuk memulai jadwal audit dari jadwal yang telah ditetapkan (Hossain dan Taylor, 1998).

$\mathbf{H}_{2}$ : Profitabilitas berpengaruh positif terhadap audit delay.

\subsubsection{Pengaruh Fee Audit Terhadap Audit Delay}

Fee Audit yang diberikan perusahan manufatur terhadap auditor menjadi salah satu faktor yang mengikat auditor agar senantiasa bekerja professional dan sesuai dengan timeline atau deadline yang telah diberikan. Pada penelitian sebelumnya telah dibuktikan bahwa besarnya fee audit yang diberikan akan memengaruhi audit delay yang terjadi.
$\mathbf{H}_{3}$ : Fee Audit berpengaruh positif terhadap audit delay.

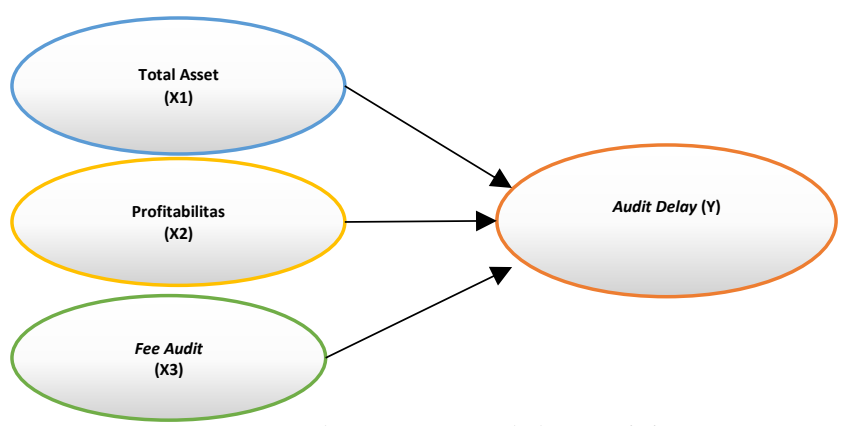

Gambar 2.1. Model Empiris

Gambar 2.1 di atas menjelaskan hubungan empiris antara total asset, profitabilitas dan fee audit terhadap audit delay.

\section{METODE PENELITIAN}

Populasi yang digunakan dalam penelitian ini adalah perusahaan industry manufaktur yang terdaftar di Bursa Efek Indonesia dan menerbitkan laporan keuangan tahunan (annual report) dan laporan keuangan (financial report) yang diaudit dan dipublikasikan di BEI untuk periode tahun 20162018.

Berdasarkan teknik purposive sampling, diperoleh sampel sebanyak 13 perusahaan dengan total konten analisis sebanyak 39 pada tahun 20162018.

Adapun pengujian yang dilakukan yaitu uji asumsi klasik yang terdiri atas uji normalitas, uji multikolinieritas, uji heteroskedastisitas, dan uji autokorelasi. Selanjutnya, untuk pengujian hipotesis dilakukan dengan cara uji signifikansi (pengaruh nyata) variabel independen $(\mathrm{X})$ terhadap variabel dependen (Y). Dalam penelitian ini digunakan analisis regresi linear berganda. Analisis regresi digunakan oleh peneliti apabila bermaksud meramalkan bagaimana keadaan (naik-turunnya) variabel dependen, dan apabila dua atau lebih variabel independen sebagai prediktor dimanipulasi atau dinaik turunkan nilainya. Untuk pengujian hipotesis yaitu dengan menggunakan analisis regresi berganda, berikut model regresi tersebut:

$$
\begin{aligned}
& \mathrm{AD}=a+b 1 T L A+b 2 P R F+b 3 F E A+e \\
& \text { Keterangan Persamaan Regresi Berganda }
\end{aligned}
$$
pada tabel 3.1 berikut ini: 
Tabel 3.1

Penjelasan Persamaan Regresi Berganda

\begin{tabular}{|l|l|}
\hline Simbol & Keterangan \\
\hline AD & Audit Delay \\
TLA & Total Asset \\
PRF & Profitabilitas \\
FEA & Fee Audit \\
$b$ & koefisien regresi \\
$a$ & konstanta \\
$e$ & Error \\
\hline
\end{tabular}

\section{HASIL DAN PEMBAHASAN}

\subsection{Hasil Analisis Statistik Deskriptif}

Metode penentuan sampel pada penelitian ini adalah purposive sampling. Sampel yang terdapat pada penelitian ini berjumlah 13 perusahaan sehingga jumlah sampel total pada 3 tahun penelitian (20162018) berjumlah 39 perusahaan.

Variabel yang digunakan pada penelitian ini adalah total asset, profitabilitas dan fee audit. Variabel-variabel ini merupakan varibel yang dapat mempengaruhi audit delay.

Tabel 4.1

Hasil Uji Analisis Statistik Deskriptif

\begin{tabular}{|c|c|c|c|c|c|}
\hline & N & Mnimum & Meximum & Mean & $\begin{array}{c}\text { std } \\
\text { Deviation }\end{array}$ \\
\hline Total Asset & 39 & 1181 & 13.96 & 12.6982 & .71941 \\
\hline Proftabilatas & 39 & -03 & 26 & .0835 & .06564 \\
\hline \multirow[t]{2}{*}{ Fee Audt } & 39 & 23500000 & 559510000 & 516493589 & 113827696 \\
\hline & & 0 & 00 & 7.00 & 20.000 \\
\hline Aust Delay & 39 & 50 & 89 & 72.21 & 11.055 \\
\hline $\begin{array}{l}\text { Vaild } N \text { : } \\
\text { (Aithino) }\end{array}$ & 39 & & & & \\
\hline
\end{tabular}

Berdasarkan Tabel 4.1 di atas, dapat dijelaskan bahwa yang pertama untuk variabel Profitabilitas perusahaan menggunakan pengukuran Laba bersih/total asset memiliki nilai rata-rata (mean) sebesar 0.0885 dengan standar deviasi sebesar 0.06964. Variabel total asset berdasarkan pengujian statistik deskriptif diukur dari natural log (total asset) memiliki rata-rata nilai (mean) sebesar 12.6982. Nilai standar deviasi sebesar 0.71941. Variabel fee audit yang diukur dari besarnya fee audit yang diterima memiliki rata-rata nilai (mean) sebesar 5164935897 dan standar deviasi 11382769620.

Selanjutnya mengenai variabel dependen audit delay dimana yang memiliki nilai maksimum sebesar 89 hari dan nilai minimum 50 hari, hal ini menunjukan bahwa semua perusahaan yang diteliti sudah mematuhi peraturan yang dibuat oleh BAPEPAM dan LK yang menyatakan bahwa emiten atau perusahaan publik yang pernyataan pendaftarannya telah menjadi efektif wajib menyampaikan laporan keuangan dan laporan akuntan kepada BAPEPAM dan LK paling lama 4 bulan (120 hari) setelah tahun buku berakhir. Nilai rata-rata (mean) dari audit delay adalah 72.21hari dengan nilai standar deviasi sebesar 11.055. Dilihat dari range tersebut bahwa sebaran data untuk audit delay perusahaan baik. Hal ini dapat dilihat dari nilai rata-rata lebih besar di banding nilai standar deviasinya. Hal ini mengindikasikan bahwa sebagian besar sampel perusahaan yang diteliti memiliki audit delay baik masih dibawah peraturan yang dikeluarkan oleh BAPEPAM dan LK.

Tabel 4.2

Hasil Uji Normalitas- One Sample Kolmogorov Smirnov

\begin{tabular}{llr} 
& & $\begin{array}{r}\text { Unstandardized } \\
\text { Residual }\end{array}$ \\
\hline N & & 39 \\
\hline Normal Parameters & Mean & .0000000 \\
\cline { 2 - 3 } & Std. Deviation & 9.31587763 \\
\hline Most Extreme Differences & Absolute & .105 \\
\cline { 2 - 3 } & Positive & .105 \\
\cline { 2 - 3 } & Negative & -.100 \\
\hline Test Statistic & & .105 \\
\hline Asymp. Sig. (2-tailed) & & $.200^{c, d}$ \\
\hline a. Test distribution is Normal. & \\
b. Calculated from data. & \\
\&. Lilliefors Significance Correction. & \\
d. This is a lower bound of the true significance. &
\end{tabular}

Berdasarkan tabel 4.2 di atas menunjukan bahwa data terdistribusi secara normal. Hal ini dapat terlihat dari tingkat signifikansi sebesar 0.2 dan nilainya di atas $\alpha=0,05$. Hal ini berarti data terdistribusi secara normal, sehingga model penelitian ini telah memenuhi uji asumsi klasik normalitas.

Tabel 4.3

Hasil Uji Multikolineritas

Collinearity Statistics

\begin{tabular}{ll|l|l}
\multicolumn{1}{c}{ Model } & \multicolumn{1}{c}{ Tolerance } & \multicolumn{1}{l}{ VIF } \\
\hline 1 & (Constant) & & \\
\cline { 2 - 4 } & Total Asset & .949 & 1.053 \\
\hline & Profitabilitas & .877 & 1.140 \\
\hline & Fee Audit & .875 & 1.142 \\
\hline
\end{tabular}

Berdasarkan Tabel 4.3 di atas, menunjukkan bahwa nilai tolerance yang dimiliki oleh total aset 
sebesar 0,949, profitabilitas sebesar 0,877, dan fee audit sebesar 0,875 Berdasarkan nilai tolerance tersebut, secara keseluruhan variabel independen memiliki nilai yang lebih besar dari 0,1 yang berarti tidak terdapat korelasi antar variabel independen. Hasil uji multikolonieritas tersebut juga menunjukkan hal yang sama tidak adanya variabel independen yang memiliki nilai VIF (Variance Inflation Factor) lebih dari 10. Nilai VIF pada variabel total aset sebesar 1,053, profitabilitas sebesar 1,140, dan fee audit sebesar 1,142. Jadi dapat disimpulkan bahwa tidak ada multikolinieritas antar variabel independen pada model regresi.

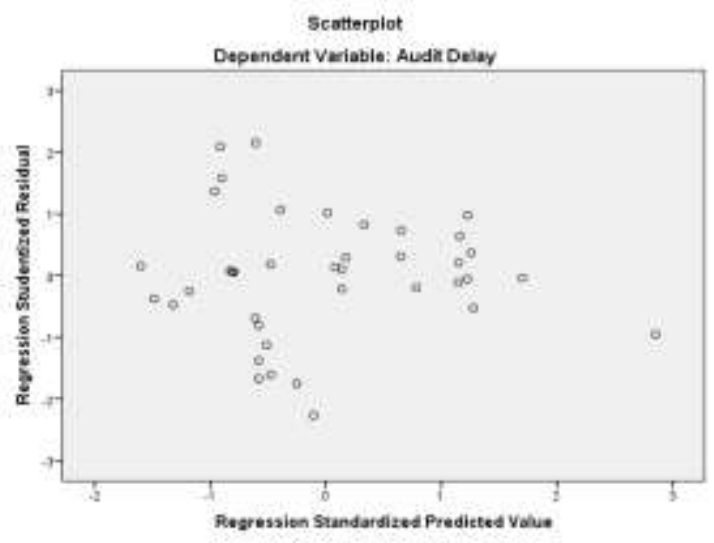

Gambar 4.1

Hasil Uji Heteroskedastistias

Berdasarkan Gambar 4.1 di atas, terlihat titiktitik menyebar secara acak. Hal ini menunjukkan bahwa model regresi tidak mengalami gangguan heteroskedastisitas.

Tabel 4.4

Hasil Uji Autokorelasi

Runs Test

\begin{tabular}{lr} 
& Unstandardized Residual \\
\hline Test Value $^{\mathrm{a}}$ & 1.17134 \\
\hline Cases $<$ Test Value & 30 \\
\hline Cases $>=$ Test Value & 30 \\
\hline Total Cases & 60 \\
\hline Number of Runs & 35 \\
\hline$Z$ & 1.042 \\
\hline Asymp. Sig. (2-tailed) & .298 \\
\hline a. Median &
\end{tabular}

Setelah dilakukan analisis data, pada tabel 4.4 diatas diperoleh nilai asymp. sig. (2-tailed) uji run test sebesar 0,298. Maka dapat disimpulkan bahwa nilai asymp.sig (2-tailed) > dari 0,05 menunjukkan tidak adanya autokorelasi positif maupun negatif pada model regresi. Maka dari itu data yang diuji dalam penelitian ini tidak menunjukkan adanya autokorelasi.
Tabel 4.5

Hasil U.ji Regresi Linier Berganda

Coefficients $^{\mathrm{a}}$

\begin{tabular}{|c|c|c|c|c|c|c|}
\hline \multirow[b]{2}{*}{ Model } & & \multicolumn{2}{|c|}{$\begin{array}{l}\text { Unstandardized } \\
\text { Coefficients }\end{array}$} & \multirow{2}{*}{$\begin{array}{c}\text { Standardized } \\
\text { Coefficients } \\
\text { Beta } \\
\end{array}$} & \multirow[b]{2}{*}{$T$} & \multirow[b]{2}{*}{ Sig. } \\
\hline & & $\mathrm{B}$ & Std. Error & & & \\
\hline \multirow[t]{4}{*}{1} & (Constant) & -4.751 & 28.502 & & -.167 & .869 \\
\hline & Total Asset & 6.021 & 2.246 & .392 & 2.680 & .011 \\
\hline & Profitabilitas & -17.690 & 24.149 & -111 & -.733 & .469 \\
\hline & Fee Audit & 3.998E-10 & .000 & .412 & 2.704 & .010 \\
\hline
\end{tabular}

Berdasarkan Tabel 4.5 di atas, dapat dinyatakan bahwa total asset berpengaruh positif signifikan terhadap audit delay, dengan hasil nilai signifikasi 0,011 yang artinya lebih kecil dari 0,05. Profitabilitas tidak berpengaruh signifikan terhadap audit delay, dengan hasil nilai signifikasi 0,469 yang artinya lebih besar dari 0,05 . Fee audit berpengaruh positif signifikan terhadap audit delay, dengan hasil signifikasi 0,010 yang artinya lebih kecil dari 0,05.

\section{KESIMPULAN DAN SARAN}

Berdasarkan tabel 4.5 di atas yang menunjukan bahwa total asset berpengaruh positif signifikan terhadap audit delay. Adapun alasan yang mendasari hasil pengujian hipotesis 1 ini adalah perusahaan yang memiliki asset yang lebih besar akan melaporkan lebih cepat dibandingkan dengan perusahaan yang memiliki asset yang lebih kecil. Hal ini disebabkan oleh perusahaan yang memiliki sumber daya (asset) yang besar memiliki lebih banyak sumber informasi, lebih banyak staf akuntansi, sistem informasi yang lebih canggih, memiliki sistem pengendalian intern yang kuat, serta adanya pengawasan dari investor, regulator dan sorotan masyarakat, maka hal ini memungkinkan perusahaan untuk melaporkan laporan keuangan auditannya lebih cepat publik.

Profitabilitas terbukti tidak memiliki pengaruh terhadap audit delay. Hal ini dikarenakan baik perusahaan yang memiliki tingkat profitabilitas yang rendah maupun tinggi tidak mendasari perubahan audit delay pada klien.

Fee audit dibuktikan dapat berpengaruh postitif signifikan terhadap audit delay. Hal ini dikarenakan fee audit yang diberikan perusahan manufatur terhadap auditor menjadi salah satu faktor yang mengikat auditor agar senantiasa bekerja professional dan sesuai dengan timeline atau deadline 
yang telah diberikan sehingga mempengaruhi panjang atau pendeknya periode audit delay.

Adapun saran yang dapat diberikan untuk penelitian selanjutnya adalah dapat menambah periode penelitian dan variasi variabel independen agar dapat digeneralisir seperti variabel opini audit, ukuran KAP, dan solvabilitas.

\section{REFERENSI}

[1] Anthony \& Govindarajan. (2005). Management Control System. Jakarta: Salemba Empat.

[2] Apriani, S. (2017). Analisis Pengaruh Profitabilitas, Ukuran Perusahaan dan Ukuran Kantor Akuntan Publik (KAP) Terhadap Audit Delay Pada Perusahaan Pertambangan Periode 2010-2014. Jurnal Riset Manajemen dan Bisnis (JRMB), 2, 261-270.

[3] Aprilia, Rosella \& Effendi, Bahtiar. (2019). Pengaruh Pergantian Manajemen, Kepemilikan Publik dan Financial Distress terhadap Auditor Switching. STATERA: Jurnal Akuntansi dan Keuangan, 1(1), 61-75.

[4] Arens, Alvin A., Elder, Randal J., \& Beasly Mark S. (2014). Auditing and Assurance Service: An Integrated Approach. 15th edition. Essex. England: Pearson Education Inc.

[5] Aryaningsih, Devi \& Budiartha. (2014). Pengaruh total aset, tingkat solvabilitas dan opini audit pada audit delay. E-Jurnal Akuntansi Universitas Udayana, 7(3), 747-647.

[6] Ashton, Robert., Willingham, Jhon. \& Elliott, Robert. (1987). An Empirical Analysis of Audit Delay. Journal of Accounting Research, 25.

[7] Effendi, B. (2018). Pengaruh Ukuran Perusahaan dan Ukuran KAP terhadap Audit Delay. At Negotium Procuratio: Jurnal Bisnis dan Manajemen, 4(1), 21-30.

[8] Effendi, B. (2018). Profitabilitas, Solvabilitas dan Audit Delay Pada Perusahaan Consumer Goods yang Terdaftar di BEI. Owner: Jurnal Riset dan Akuntansi, 2(2), 100-108.

[9] Effendi, B. (2019). Kualitas Audit, Kondisi

Keuangan, Ukuran Perusahaan dan Penerimaan Opini Audit Going Concern. Owner: Jurnal Riset dan Akuntansi, 3(1), 9-15.

[10] Effendi, B. (2019). Kondisi Keuangan, Opinion Shopping dan Opini Audit Going Concern pada Perusahaan Pertambangan yang Terdaftar di BEI. STATERA: Jurnal Akuntansi dan Keuangan, 1(1), 34-46.
[11] Effendi, B. (2019). Role Conflict, Role Ambiguity, Independensi dan Kinerja Auditor. STATERA: Jurnal Akuntansi dan Keuangan, 1(2), 155-166.

[12] Effendi, B. (2019). Komite Audit, Profitabilitas, Solvabilitas, dan Ketepatan Waktu Pelaporan Keuangan Perusahaan Manufaktur-Sektor Logam. Business Innovation and Entrepreneurship Journal, 1(3), 149-157.

[13] Febriyanti. (2011). Faktor-Faktor Yang Berpengaruh Terhadap Audit Delay Perusahaan Sektor Perdagangan Yang Terdaftar Di Bei Periode 2007-2009. Jurnal Ekonomi Dan Informasi Akuntansi (Jenius), 3.

[14] Ghozali, H. Imam. (2016). Aplikasi Analisis Multivariete Dengan Program IBM SPSS 23. Semarang.

[15] Hossain, Monirul. \& Taylor, Peter. (1998). An Examination of Audit Delay: Evidence from Pakistan. Journal of Accounting Research.

[16] Ikatan Akuntan Indonesia. (2018). Standar Profesional Akuntan Publik. Jakarta: Salemba Empat.

[17] Ismail, H., Mustapha M., \& Ming, C. (2012). Timeliness of Audited Financual Report of Malaysian Listed Companies. International Journal of Business and Social Science.

[18] Jensen, Michael C., \& William H. Meckling, (1976). Theory of The Firm: Managerial Behavior, Agency and Ownership Structure. Journal of Financial Economics, 3(4), 305-360.

[19] Kharissa, D. (2018). Pengaruh Total Aktiva, ROA dan DAR terhadap Audit Delay. Jurnal Administrasi Bisnis (JAB), 58(2).

[20] Lestari, Ni Luh, \& Made Yenni Latrini. (2018). Pengaruh Fee Audit, Ukuran Perusahaan Klien, Ukuran Kap, dan Opini Auditor Pada Audit Delay. E-Jurnal Akuntansi Universitas Udayana, 24(1), 422-450.

[21] Subekti, Imam \& Widiyanti. (2004). Faktorfaktor yang berpengaruh terhadap Audit Delay di Indonesia. Simposium Nasional Akuntansi VII Denpasar.

[22] Susiyanti, Susiyanti \& Effendi, Bahtiar. (2019). Struktur Modal, Ukuran Perusahaan, Likuiditas dan Profitabilitas Perusahaan Manufaktur yang Listing di BEI. Owner: Jurnal Riset dan Akuntansi, 3(2), 66-72.

[23] Utami, W. (2006). Analisis Determinan Audit Delay Kajian Empiris Di Bursa Efek Indonesia. Bulletin Penelitian No.09 Tahun 2006. 